EVALUASI, 4 (1), Maret 2020, ISSN 2580-3387 (print) |

ISSN 2615-2886 (online)

Homepage : http://e-journal.staima-alhikam.ac.id/index.php/evaluasi

DOI : : http://doi.org/10.32478/evaluasi.v4i1.342

Article type : Original Research Article

\title{
Pengaruh Gaya Kepemimpinan Tansformational, Authentic Authoritarian, dan Transactional Terhadap Kinerja Guru Madrasah Aliyah di Tangerang
}

\author{
Agus Purwanto*, Riza Primahendra, Ardian Sopa, Sekundina Williana \\ Kusumaningsih, Rudy Pramono
}

Universitas Pelita Harapan, Tangerang

\begin{abstract}
The purpose of this study was to analyze the influence of transformational, transactional, authentic and authoritarian leadership styles on teacher performance in an Aliyah Madrasah in Tangerang, Banten. The respondents of this study were 100 teachers and the method of data collection was by distributing electronic questionnaires to the teachers. Data analysis in this study uses SEM (Structural Equation Model) LISREL program version 8.70. The results of the analysis and processing of research data indicate that it shows that the leadership, transactional and authorian styles of Madrasah Aliyah in Tangerang show a positive and significant effect on teacher performance while the transformational and authentic leadership styles do not significantly influence teacher performance.
\end{abstract}

Keywords: Transformational Leadership Style, Transactional, Authentic and Authoritarian, Teacher Performance

\section{Abstrak}

Tujuan dari penelitian ini adalah untuk menganalisis pengaruh gaya kepemimpinan transformational, transactional, authentic dan authoritarian terhadap kinerja guru di sebuah Madrasah Aliyah di Tangerang Banten. Responden dari penelitian ini adalah guru sebanyak 100 orang guru dan metode untuk pengumpulan data dengan cara mendistribusikan kuesioner elektronik secara online ke para guru

20 Corresponding author: agozpor@gmail.com

EVALUASI: Jurnal Manajemen Pendidikan Islam is licensed under

The CC BY License (https://creativecommons.org/licenses/by-sa/4.0/) 
EVALUASI, 4 (1), Maret 2020, ISSN 2580-3387 (print) |

ISSN 2615-2886 (online)

Homepage : http://e-journal.staima-alhikam.ac.id/index.php/evaluasi

DOI : : http://doi.org/10.32478/evaluasi.v4i1.342

Article type : Original Research Article

madrasah. Analisis data dalam penelitian ini dengan menggunakan metode SEM (Structural Equation Model) program LISREL versi 8.70. Hasil dari analisis dan pengolahan data penelitian telah menunjukkan bahwa gaya kepemimpinan transactional dan authorian pada Madrasah Aliyah di Tangerang menunjukkan berpengaruh secara positif dan signifikan terhadap kinerja guru madrasah aliyah sedangkan gaya kepemimpinan transformational dan authentic tidak berpengaruh signifikan terhadap kinerja guru madrasah aliyah.

Kata kunci: Gaya Kepemimpinan Transformational, Transactional, Authentic dan Authoritarian, Kinerja Guru

\section{PENDAHULUAN}

Pendidikan di Indonesia makin berkembang pesat dan menghadapi berbagai problematika dan tantangan yang tidak sama dari masa ke masa. Setiap masa memiliki tantangan masing-masing yang harus disikapi dengan evaluasi kebijakan pendidikan tinggi yang dinamis dan kompeten. Masalah Dunia Pendidikan Salah satu masalah mendasar yang dihadapi perguruan tinggi adalah problem relevansi dan mutu yang belum menggembirakan. Pendidikan belum bisa menjadi faktor penting yang mampu melahirkan enterpreneur dengan orientasi job creating dan kemandirian. Pengangguran terdidik dari hasil pendidikan terus bertambah, problem pengabdian masyarakat dimana perguruan tinggi tersebut berada dirasa kurang responsif, dan berkontribusi terhadap problem masyarakat. Kepemimpinan manajerial dan gaya kepemimpinan organisasi sekolah, dalam bentuk organisasi jasa, juga menggunakan sistem manajemen strategi pendidikan nasional berdasarkan Panca Sila dan Undang-Undang Dasar Negara Republik Indonesia Tahun 1945 yang berakar pada nilai-nilai agama, kebudayaaan nasional Indonesia dan tanggap terhadap tuntutan zaman (Pasal 1:UndangUndang RI No. 20 Tahun 2003 tentang Sistem Pendidikan Nasional).Struktur dan manajemen perguruan tinggi yang berlangsung dalam hubungan keterkaitan interaktif komunikasinya, selalu dihadapkan pada faktor manuia,baik di dalam proses komunikasi organisasi internal maupun 
EVALUASI, 4 (1), Maret 2020, ISSN 2580-3387 (print) I

ISSN 2615-2886 (online)

Homepage : http://e-journal.staima-alhikam.ac.id/index.php/evaluasi

DOI : : http://doi.org/10.32478/evaluasi.v4i1.342

Article type : Original Research Article

eksternal. Termasuk faktor-faktor diluar kendali manajer itu sendiri yaitu kondisi lingkungan ${ }^{1}$.

Beberapa penelitian sebelumnya yang dimulai dengan topik pengaruh gaya kepemimpinan terhadap kinerja bahwa jenis gaya kepemimpinan transformational berpengaruh positif dan signifikan terhadap kinerja, tipe gaya kepemimpinan transactional berpengaruh negatif signifikan terhadap kinerja ${ }^{2}$. Dampak kepemimpinan transformational pada kinerja karyawan, dan kepemimpinan transactional tidak mempengaruhi kinerja karyawan. Pengaruh gaya kepemimpinan transformational terhadap kinerja dan gaya kepemimpinan transactional tidak mempengaruhi kinerja. Jenis kepemimpinan transformational negatif dan tidak signifikan mempengaruhi kinerja kepemimpinan transactional karyawan sementara tidak ada pengaruh yang signifikan terhadap kinerja karyawan. Gaya kepemimpinan transformational memiliki pengaruh signifikan terhadap kepuasan kerja, jenis kepemimpinan transformational tidak memiliki pengaruh yang signifikan terhadap kinerja guru, budaya organisasi tidak memiliki dampak yang signifikan terhadap kinerja guru, dan kepuasan kerja tidak berpengaruh secara signifikan terhadap kinerja guru . Untuk meningkatkan kinerja guru dapat dilakukan dengan cara meningkatkan kepuasan kerja jika kepuasan kerja semakin meningkat, maka kinerja guru juga akan semakin meningkat. Gaya kepemimpinan transformational dan gaya kepemimpinan transactional memiliki efek yang cukup kuat dan positif pada kinerja organisasi setelah mengendalikan dampak kepemimpinan transactional ${ }^{3}$.

${ }^{1}$ Alavi,Seyyed Babak and Gill, Carol, (2016). Leading Change Authentically: How Authentic Leaders Influence Follower Responses to Complex Change. Journal of Leadership \& Organizational Studies, Issue DOI: 10.1177/1548051816664681, pp. 1- 15.

${ }^{2}$ Alonderiene, R. and Majauskaite, M. (2016), "Leadership style and job satisfaction in higher education institutions", International Journal of Educational Management, Vol. 30 No. 1, pp. 140-164. https://doi.org/10.1108/IJEM-08-2014-0106

${ }^{3}$ Al-Musadieq, Muhammad, Nurjannah, Raharjo, Kusdi,Solimun and Fernandes, Adji Achmad Rinaldo, (2018). "The mediating effect of work motivation on the influence of job design and organizational. Journal of Management Development, 10( Emerald Publishing Limited). 
EVALUASI, 4 (1), Maret 2020, ISSN 2580-3387 (print) |

ISSN 2615-2886 (online)

Homepage : http://e-journal.staima-alhikam.ac.id/index.php/evaluasi

DOI : : http://doi.org/10.32478/evaluasi.v4i1.342

Article type : Original Research Article

Pengaruh faktor-faktor organisasional dari desain pekerjaan terhadap peningkatan kinerja staf terbukti signifikan dengan aspek motivasi motivasi kerja, penelitian ini juga menemukan hubungan praktis tidak langsung antara budaya organisasi dan variabel intervening dari motivasi kerja. Seorang pemimpin dapat dianggap sebagai pemimpin yang sukses jika berdasarkan pengukuran ia mampu mempengaruhi dan mengembangkan orang-orang yang dipimpinnya. Ciri-ciri yang baik dari seorang pemimpin adalah kepedulian dan peka terhadap kebutuhan orang-orang yang dipimpinnya bahwa bawahan dapat didekati dan bersedia untuk mendiskusikan impian dan harapan mereka4. Ada beberapa jenis model kepemimpinan yang tampak dalam organisasi mana pun, ada beberapa yang sangat berpengaruh. Penelitian ini dilakukan untuk melihat kepemimpinan seperti apa yang sangat efektif untuk mempengaruhi kinerja perkuliahan yang akan membawa dampak signifikan pada kinerja semua perkuliahan. Sehubungan dengan berbagai model kepemimpinan, penelitian ini memeriksa apakah kepemimpinan transformational, kepemimpinan transactional, kepemimpinan authentic atau kepemimpinan authoritarian akan secara signifikan mempengaruhi kinerja guru madrasah di Tangerang.

Dalam Undang-Undang Nomor 14 Tahun 2005 tentang guru dan guru, guru dinyatakan sebagai pendidik dan ilmuwan profesional dengan tugas utama mengubah, mengembangkan, dan menyebarluaskan ilmu pengetahuan, teknologi, dan seni melalui pendidikan, penelitian, dan pengabdian kepada masyarakat (Bab 1 Pasal 1 ayat 2). Tugas utama guru adalah melaksanakan tri dharma pendidikan tinggi dengan beban kerja minimal 12 (dua belas) kredit dan maksimum 16 (enam) dua belas) kredit di setiap semester sesuai dengan kualifikasi akademik. Pelaksanaan tugas utama guru ini perlu dievaluasi dan dilaporkan secara berkala sebagai bentuk pertanggungjawaban kinerja guru kepada pemangku kepentingan (Dirjen Dikti, 2010: 1).

Tujuan dari penelitian ini adalah untuk menganalisis pengaruh gaya kepemimpinan transformational, transactional, authentic dan authoritarian terhadap kinerja guru madrasah aliah di Tangerang.

\footnotetext{
${ }^{4}$ Anon., n.d. Beverly Alimo-Metcalfe and Robert J. Alban-Metcalfe, 2001. The development of a new Transformational Leadership Questionnaire. Journal of Occutangerangonal and Organizational Psychology, 74(The British Psychological Society), pp. 1-27.
} 
EVALUASI, 4 (1), Maret 2020, ISSN 2580-3387 (print) |

ISSN 2615-2886 (online)

Homepage : http://e-journal.staima-alhikam.ac.id/index.php/evaluasi

DOI : $\quad:$ http://doi.org/10.32478/evaluasi.v4i1.342

Article type : Original Research Article

\section{TINJAUAN PUSTAKA}

\section{Kepemimpinan}

Kepemimpinan adalah kemampuan untuk mempengaruhi perilaku orang untuk mencapai tujuan tertentu dalam situasi tertentu. Kepemimpinan selalu berkorelasi dengan kepedulian sosial yang berarti ada interaksi antara pemimpin dengan yang dipimpinnya untuk mencapai tujuan dan sasaran yang sama.

\section{Kepemimpinan Transformational}

Empat komponen transformational: pengaruh ideal pemimpin transformational menjalani hidup mereka untuk dikagumi, dihormati dan dipercaya oleh pengikut mereka; motivasi inspirasional pemimpin transformational memotivasi dan menginspirasi orang-orang di sekitar mereka dengan menawarkan makna, optimisme dan antusiasme untuk visi kondisi masa depan; stimulasi intelektual: pemimpin transformational mendorong pengikut menjadi kreatif dan inovatif untuk menyelesaikan masalah dengan cara baru dan untuk tidak membuat asumsi; secara individual pemimpin transformational mempertimbangan serta mengusahakan secara aktif potensi pengikut mereka dengan menghasilkan peluang baru untuk pengembangan dan secara konsisten melatih, membimbing, dan memperhatikan kebutuhan dan keinginan pengikut, daripada memantau upaya mereka. Gaya transformational menuju kepemimpinan menggarisbawahi emosi dan norma kemudian saling berbagi tujuan dasar untuk memelihara kemajuan kapasitas dan tingkat lanjutan komitmen seseorang terhadap tujuan organisasi. Kepemimpinan transformational dengan kepemimpinan transactional dan menyatakan bahwa hasil kepemimpinan transformational dalam pencapaian yang melebihi apa yang diharapkan.

Kepemimpinan Transformational menyerukan nilai-nilai moral dari pengikut dalam upaya mereka untuk meningkatkan kesadaran mereka tentang masalah etika dan untuk memobilisasi energi dan sumber daya 
EVALUASI, 4 (1), Maret 2020, ISSN 2580-3387 (print) |

ISSN 2615-2886 (online)

Homepage : http://e-journal.staima-alhikam.ac.id/index.php/evaluasi

DOI : : http://doi.org/10.32478/evaluasi.v4i1.342

Article type : Original Research Article

mereka ke lembaga reformasi ${ }^{5}$. Kepemimpinan transformational didefinisikan sebagai pemimpin yang memiliki kekuatan untuk mempengaruhi bawahannya dengan cara tertentu, kepemimpinan transformational didefinisikan sebagai pemimpin yang memperkuat kerja sama timbal balik dan pembelajaran tim. Kepemimpinan transformational adalah gaya kepemimpinan yang digunakan oleh seorang manajer jika ia ingin suatu kelompok memperluas batasannya dan memiliki kinerja di luar status quo atau mencapai serangkaian tujuan organisasi yang sama sekali baru. Pemimpin transformational dapat berhasil mengubah status quo dalam organisasi mereka dengan mempraktikkan perilaku yang sesuai pada setiap tahap proses transformasi. Kepemimpinan transformational adalah kepemimpinan yang lebih dari sekadar pertukaran atau penghargaan untuk kinerja yang ditunjukkan oleh pengikut tetapi lebih didasarkan pada kepercayaan dan komitmen Pemimpin transformational memperhatikan kebutuhan pengembangan masing-masing pengikut dan masalah dengan membantu mereka melihat masalah lama dengan cara baru, dan mereka mampu memotivasi, memelihara, merangsang, membangkitkan, dan menginspirasi pengikut untuk melakukan upaya ekstra untuk mencapai tujuan kelompok. Kepemimpinan transformational ini benar-benar disebut kepemimpinan sejati karena kepemimpinan ini benar-benar bekerja menuju tujuan yang mengarahkan organisasi ke tujuan yang tidak pernah dicapai sebelumnya dan dengan kepemimpinan transformational, bawahan akan merasa dipercaya, dihargai dan bawahan akan lebih menghargai pemimpin mereka ${ }^{6}$.

Dimensi kepemimpinan transformational, seperti Kharisma adalah kemampuan pemimpin untuk membangkitkan kebanggaan, kepercayaan dan rasa hormat terhadap bawahan mereka dan mampu secara efektif

5 Asbari, M., Santoso, P., \& Purwanto, A. (2019). Pengaruh Kepemimpinan dan Budaya Organisasi Terhadap Perilaku Kerja Inovatif Pada Industri 4.0. JIM UPB (Jurnal Ilmiah Manajemen Universitas Putera Batam), 8(1), 7-15. doi: https://doi.org/10.33884/jimupb.v8i1.1562

${ }^{6}$ Asbari, M., Nurhayati, W., \& Purwanto, A. (2019). Pengaruh Parenting style dan Personality Genetic Terhadap Pengembangan Karakter Anak di Paud Islamic School. JURNAL AUDI: Jurnal Ilmiah Kajian Ilmu Anak dan Media Informasi PAUD, 4(2), 148-

163.http://ejurnal.unisri.ac.id/index.php/jpaud/article/view/3344 
EVALUASI, 4 (1), Maret 2020, ISSN 2580-3387 (print) |

ISSN 2615-2886 (online)

Homepage : http://e-journal.staima-alhikam.ac.id/index.php/evaluasi

DOI : : http://doi.org/10.32478/evaluasi.v4i1.342

Article type : Original Research Article

mengkomunikasikan misi dan visi organisasi yang mereka pimpin, menggambarkan sejauh mana seorang pemimpin mengkomunikasikan visi yang menarik, menggunakan simbol untuk memfokuskan upaya bawahan dan mengekspresikan tujuan penting dengan cara yang sederhana. Rangsangan intelektual, adalah perilaku pemimpin yang mendorong bawahan mereka untuk selalu berinovasi dan menjadi kreatif dalam menyelesaikan masalah yang mereka hadapi, menawarkan ide-ide baru untuk merangsang bawahan mereka untuk memikirkan kembali cara lama menyelesaikan pekerjaan dan mempengaruhi bawahan untuk melihat masalah - masalah dari perspektif baru. Pertimbangan individual, adalah perilaku pemimpin yang selalu peduli dengan pengembangan kemampuan bawahan mereka, memperlakukan bawahan sebagai individu, berusaha memahami keinginan bawahan dan berfungsi sebagai penasihat.

\section{Gaya Kepemimpinan Transactional}

Definisi kepemimpinan transactional tidak dapat dipisahkan dari Burn (1978), yaitu kepemimpinan yang berhubungan dengan pengikut yang memotivasi dengan menyerukan kepentingan pribadi mereka (Yukl 2010: 290). Menurut Yukl (2010: 291) kepemimpinan transactional dapat melibatkan nilai-nilai, tetapi nilai-nilai itu relevan dengan proses pertukaran seperti kejujuran, tanggung jawab, dan timbal balik. Bass (dalam Yukl 1998: 125) mengemukakan bahwa hubungan pemimpin transactional dengan bawahannya tercermin dalam tiga hal, Pemimpin tahu apa yang diinginkan bawahan dan akan menjelaskan apa yang akan diperoleh bawahan jika pekerjaan itu sesuai dengan harapan. Pemimpin bertukar upaya yang dilakukan oleh bawahan sebagai imbalan. Pemimpin responsif terhadap kepentingan pribadi bawahan selama kepentingan itu proporsional dengan nilai pekerjaan yang dilakukan oleh bawahan.

Karakteristik kepemimpinan transactional terdiri dari dua aspek, imbalan kontingen adalah pemimpin menginformasikan kepada bawahannya tentang apa yang harus dilakukan bawahan mereka jika mereka ingin mendapatkan hadiah tertentu dan menjamin bahwa bawahan akan mendapatkan apa yang mereka inginkan sebagai pengganti upaya yang dilakukan. Manajemen pengecualian adalah pemimpin yang berusaha 
EVALUASI, 4 (1), Maret 2020, ISSN 2580-3387 (print) |

ISSN 2615-2886 (online)

Homepage : http://e-journal.staima-alhikam.ac.id/index.php/evaluasi

DOI : : http://doi.org/10.32478/evaluasi.v4i1.342

Article type : Original Research Article

mempertahankan prestasi dan cara kerja bawahannya, jika ada kesalahan, pemimpin tersebut segera bertindak untuk memperbaikinya ${ }^{7}$.

\section{Kepemimpinan Authentic}

Selain kepemimpinan transformational, jenis kepemimpinan hebat lainnya adalah kepemimpinan authentic. Kepemimpinan authentic mirip dengan tipe transformational, juga memiliki empat dimensi. Kesadaran diri memiliki sifat berlapis-lapis dari diri yang berisi menemukan wawasan ke dalam diri melalui paparan kepada orang lain dan berkenalan dengan dampak pada orang lain, dengan kata lain kesadaran diri ditunjukkan dengan menunjukkan pemahaman tentang potensi dan keterbatasan setiap orang. Transparansi relasional adalah dimensi kedua yang menghadirkan diri yang otentik kepada orang lain dengan menciptakan kepercayaan melalui keterbukaan yang berarti bersedia berbagi emosi dan pikiran yang paling dalam sambil mengurangi reaksi dan perilaku yang tidak pantas. Kepemimpinan memiliki bakat, terutama untuk penyesuaian beragam organisasi karena efisiensi untuk membawa perubahan dengan beberapa metode dalam pengembangan organisasi. Pemimpin authentic telah mencapai tingkat keaslian tinggi dalam identitas diri mereka bahwa mereka menerapkan keyakinan kuat mereka terhadap serangkaian nilai sementara jelas berbaur dengan orang lain. Itu menyatakan bahwa kepemimpinan authentic merangsang beberapa cara motivasi dan pembelajaran dalam pengikut selama proses perubahan, yang membantu pelaksanaan perubahan yang efektif. Keaslian berarti 'kenalilah dirimu sendiri' diprakarsai oleh filsuf Yunani kuno Socrates yang memiliki pengalaman individual, termasuk persepsi diri tentang pandangannya sendiri, suasana hati, keinginan, kecenderungan ${ }^{8}$.

\footnotetext{
${ }^{7}$ Bosch, D., (2013). The Impact of Transformational Leadership on Leader-Follower Work Value Congruence. International Journal of Business and Social Research (IJBSR),, Volume vol. 3 no 8, pp. 18-31.

8 Chukwusa, J., (2019). Autocratic Leadership Style: Obstacle to Success in Academic Libraries. Library Philosophy and Practice e-Journal, Issue DigitalCommons@University of Nebraska - Lincoln. Chu, L.-C., 2013. The moderating role of authoritarian leadership on the relationship between the internalization of emotional regulation and the well-being of employees. Leadership, Issue DOI: $10.1177 / 1742715013498403$, p. 1-18.
} 
EVALUASI, 4 (1), Maret 2020, ISSN 2580-3387 (print) |

ISSN 2615-2886 (online)

Homepage : http://e-journal.staima-alhikam.ac.id/index.php/evaluasi

DOI : : http://doi.org/10.32478/evaluasi.v4i1.342

Article type : Original Research Article

\section{Kepemimpinan Authoritarian}

kepemimpinan authoritarian sebagai gaya kepemimpinan yang ditandai oleh pemimpin yang mempertahankan kekuasaan dan otoritas pengambilan keputusan sebanyak mungkin. Para pemimpin telah menyusun koleksi ganjaran dan hukuman serta mengoperasikan ancaman dan hukuman untuk mengendalikan bawahan, yang idenya hampir tidak pernah terdengar. Gaya kepemimpinan authoritarian tidak akan memotivasi bawahan, dan menuntut pekerjaan yang harus diselesaikan segera. Para pemimpin ini diyakini sebagai pengendali bahwa bawahan hanya perlu membawa hasilnya berdasarkan spesifikasi pemimpin. Seringkali, pemimpin authoritarian datang dengan solusi yang tidak terlalu inventif, oleh karena itu akan menurunkan pengabdian pengikut terhadap tugas-tugas dan perilaku authoritarian pengawas timbul negatif. Ada empat aspek penting menurut yaitu (1) wewenang dan kontrol, artinya tidak mau mendelegasikan, hanya melibatkan interaksi top-down, mengendalikan data sehingga ragu-ragu, dan sungguhsungguh memonitor junior, (2) memandang rendah kompetensi bawahan, karena itu tidak akan mendengar ide dan masukan bawahan, (3) membangun citra, yang membuat para pemimpin untuk menjaga harga diri mereka sendiri dengan percaya diri untuk memanipulasi catatan terkait dan (4) perilaku didaktik, yang berarti beberapa tuntutan pada pencapaian dan perilaku tertentu dan jika gagal, teguran dan teguran keras terjadi yang akan menghasilkan emosi negatif pada bawahan, seperti amarah, agresi, dan kecemasan ketika ada beberapa staf yang tidak terlatih yang bingung bagaimana melakukan atau teknik yang harus diikuti kemudian ada teknik yang kuat namun efektif dapat disampaikan secara detail ${ }^{9}$.

\section{Kinerja Guru}

Menurut Direktur Jenderal Pendidikan Tinggi (2010: 7), guru memiliki tugas pokok sebagai berikut. Tugas menyelenggarakan pendidikan adalah tugas di bidang pendidikan dan pengajaran, termasuk melakukan kuliah /

${ }^{9}$ Corbin, B., (2000). Entrepreneurial Leadership: Fundamentals. Carmel: Corbin Group Publishing. Erkutlu, H., 2008. The impact of transformational leadership on organizational and leadership effectiveness. Journal of Management Development, Vol. 27 (No. 7), pp. 708-726. 
EVALUASI, 4 (1), Maret 2020, ISSN 2580-3387 (print) |

ISSN 2615-2886 (online)

Homepage : http://e-journal.staima-alhikam.ac.id/index.php/evaluasi

DOI : : http://doi.org/10.32478/evaluasi.v4i1.342

Article type : Original Research Article

tutorial dan menguji dan mengatur kegiatan pendidikan di laboratorium, praktik guru, praktik lokakarya / studio / kebun percobaan / teknologi pengajaran, membimbing seminar siswa, membimbing kuliah kerja (KKN), praktik kerja nyata (PKN), praktik kerja lapangan (PKL), memandu tugas akhir penelitian mahasiswa termasuk membimbing, membuat laporan akhir dari hasil penelitian, penguji pada ujian akhir, membina kegiatan siswa di bidang akademik dan bidang kemahasiswaan, mengembangkan program kuliah, mengembangkan bahan ajar, menyampaikan pidato ilmiah, membina kegiatan siswa di bidang akademik dan kemahasiswaan, membimbing guru tingkat bawah, melaksanakan pelatihan guru dan kegiatan transplantasi.Tugas melakukan pengabdian masyarakat mencakup menduduki posisi kepemimpinan di lembaga pemerintah atau pejabat negara sehingga mereka harus dilepaskan dari posisi organik mereka, melaksanakan pengembangan hasil pendidikan dan penelitian yang dapat dimanfaatkan oleh masyarakat, memberikan pelatihan dan konseling / peningkatan ke masyarakat, memberikan layanan kepada masyarakat atau kegiatan lain yang mendukung pelaksanaan pemerintahan umum dan tugas pembangunan, membuat dan menulis layanan masyarakat (DirjenDikti, 2010: 7). Tugas mendukung tiga-tri dharma pendidikan tinggi termasuk menjadi anggota komite atau badan di pendidikan tinggi, menjadi anggota badan di lembaga pemerintah, menjadi anggota organisasi profesional, mewakili lembaga - lembaga pemerintah duduk di komite antar lembaga, menjadi anggota delegasi nasional untuk pertemuan internasional, berpartisipasi dan aktif dalam pertemuan ilmiah, mendapatkan penghargaan layanan, penghargaan, menulis buku teks sekolah menengah atas, memiliki prestasi di bidang olahraga, seni, sosial (Direktur Jenderal Pendidikan Tinggi, 2010).

\section{METODE}

Analisis data penelitian ini menggunakan metode Structural Equation Model (SEM) dan menggunakan software Linear Structural Model (LISREL) versi 8.70. metode pengumpulan data dengan memberikan kuesioner elektronik kepada seluruh guru. Responden penelitian adalah guru di sebuah Madrasah Aliyah di Tangerang sebanyak 100 orang. 
EVALUASI, 4 (1), Maret 2020, ISSN 2580-3387 (print) |

ISSN 2615-2886 (online)

Homepage : http://e-journal.staima-alhikam.ac.id/index.php/evaluasi

DOI : : http://doi.org/10.32478/evaluasi.v4i1.342

Article type : Original Research Article

Tabel 1 Profil Responden Guru

\begin{tabular}{|c|c|c|c|}
\hline Masa Kerja & Laki-laki & Perempuan & Total \\
\hline 0-3 Tahun & 14 & 16 & 30 \\
\hline 3-6 Tahun & 12 & 8 & 20 \\
\hline 6-10 Tahun & 19 & 17 & 36 \\
\hline Lebih dari 10 Tahun & 8 & 6 & 14 \\
\hline \multicolumn{2}{|c}{ T O T A L } \\
\hline
\end{tabular}

Berdasarkan tablel diatas dari sebanyak 100 orang responden guru madrasah aliyah diperoleh responden paling banyak guru dengan masa kerja dibawah 3 tahun sebanyak 30 guru dengan perincian guru laki-laki sebanyak 14 dan guru perempuan sebanyak 16 guru. Selanjutnya guru dengan masa kerja dibawah 3 sampai dengan 6 tahun sebanyak 20 guru dengan perincian guru laki-laki sebanyak 12 dan guru perempuan sebanyak 8 guru. Selanjutnya guru dengan masa kerja dibawah 6 sampai dengan 10 tahun sebanyak 36 guru dengan perincian guru laki-laki sebanyak 19 guru dan guru perempuan sebanyak 17 guru Dan guru dengan masa kerja diatas 10 tahun tahun sebanyak 14 guru dengan perincian guru laki-laki sebanyak 8 guru dan guru perempuan sebanyak 6 guru. Untuk status guru ada dua yaitu tetap dan tidak tetap, untuk guru tetap sebanyak 60 guru dengan perincian laki-laki sebanyak 40 guru dan perempuan sebanyak 20 guru. Sedangkan guru tidak tetap sebanyak 40 guru dengan perincian laki-laki sebanyak 30 guru dan perempuan sebanyak 10 guru sehingga distribusi dari 100 responden guru sudah mewakili mayoritas populasi guru.

Berdasarkan penelitian sebelumnya dan tujuan penulisan penelitian ini, maka akan dibuat model penelitian sebagai berikut: 
EVALUASI, 4 (1), Maret 2020, ISSN 2580-3387 (print) |

ISSN 2615-2886 (online)

Homepage : http://e-journal.staima-alhikam.ac.id/index.php/evaluasi

DOI : http://doi.org/10.32478/evaluasi.v4i1.342

Article type : Original Research Article

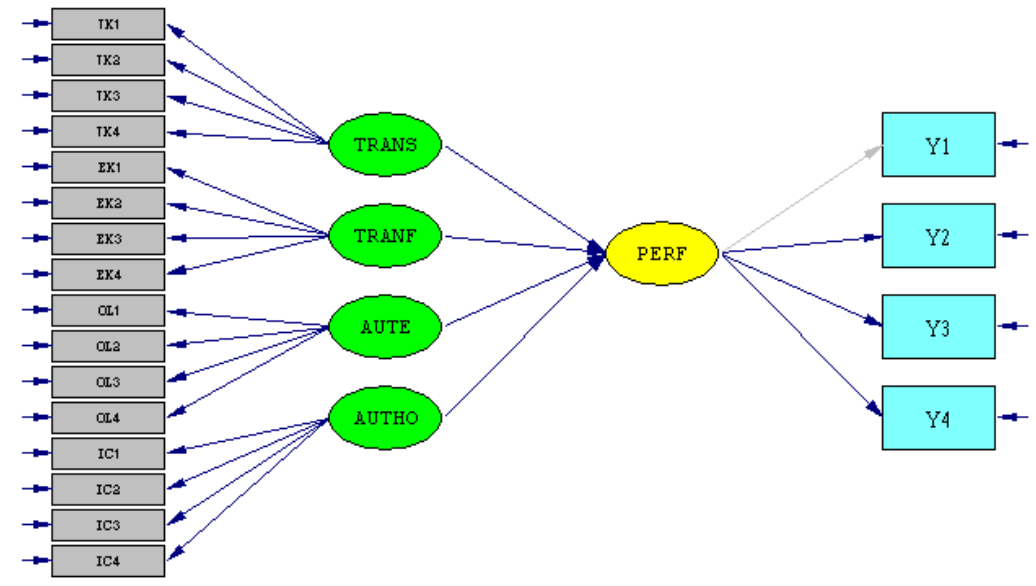

\section{Gambar 1 Model Penelitian}

Catatan : Gambar 1 berasal dari output program Lisrel (penulis, 2019) Berdasarkan model penelitian di atas akan dibuat hipotesis berikut:

1. H1 : Ada hubungan yang positif dan signifikan antara gaya Kepemimpinan Transactional (X1) dengan tingkat Kinerja Guru madrasah aliyah $(\mathrm{Y})$.

2. H2 : Ada hubungan yang positif dan signifikan antara Kepemimpinan Transformational (X2) dengan tingkat kinerja guru madrasah aliyah (Y).

3. H3 : Ada hubungan yang positif dan signifikan antara Kepemimpinan Authentic (X3) dengan tingkat kinerja guru madrasah aliyah(Y).

4. H4 : Ada hubungan yang positif dan signifikan antara Kepemimpinan Authoritarian (X4) dengan tingkat kinerja guru madrasah aliyah ( $\mathrm{Y}$ ).

Distribusi data kuesioner elektronik dilakukan dari mulai bulan November hingga Desember 2019 di Madrasah Aliyah di Tangerang.

\section{HASIL DAN DISKUSI}

Langkah pertama adalah membuat program sintaks pada software Lisrell setelah itu program dijalankan untuk mendapatkan faktor pemuatan Kepemimpinan Transactional (X1), Kepemimpinan Transformational (X2) 
EVALUASI, 4 (1), Maret 2020, ISSN 2580-3387 (print) |

ISSN 2615-2886 (online)

Homepage : http://e-journal.staima-alhikam.ac.id/index.php/evaluasi

DOI : $\quad:$ http://doi.org/10.32478/evaluasi.v4i1.342

Article type : Original Research Article

Kepemimpinan Authentic (X3), Kepemimpinan Authoritarian (X4), dan Kinerja Kuliah (PERF). Analisis data penelitian ini dilakukan menggunakan Structural Equation Model (SEM) dengan software Linear Structural Model (LISREL) versi 8.70 dari Joreskog dan Sorbom (2008), dan hasilnya adalah dalam gambar berikut :

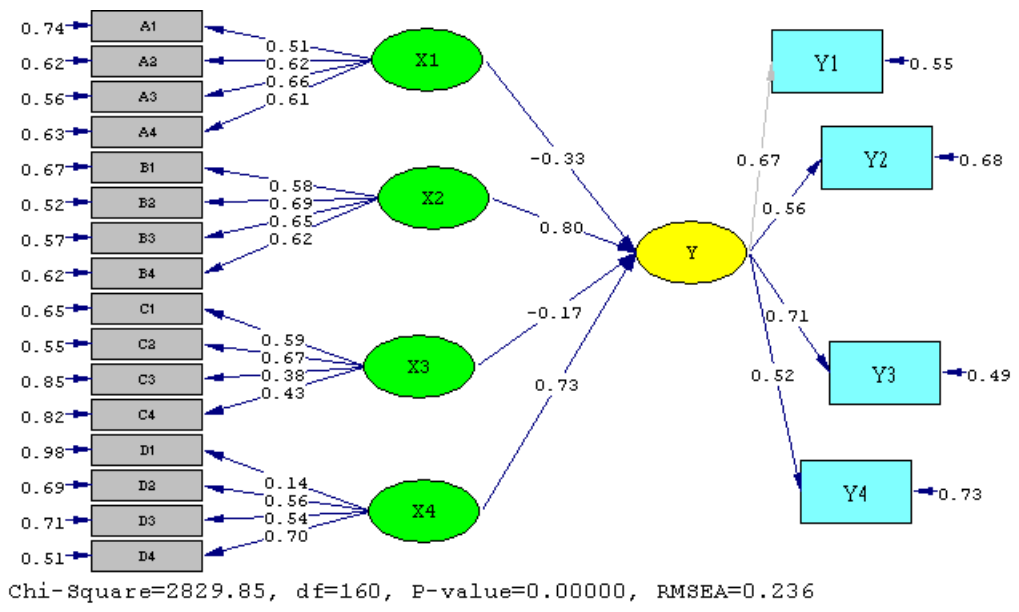

Ganbar 2 Memuat Nilai t setiap Indikator Catatan : Gambar berasal dari proses output program Lisrel (penulis, 2019) 
EVALUASI, 4 (1), Maret 2020, ISSN 2580-3387 (print) |

ISSN 2615-2886 (online)

Homepage : http://e-journal.staima-alhikam.ac.id/index.php/evaluasi

DOI : $\quad$ http://doi.org/10.32478/evaluasi.v4i1.342

Article type : Original Research Article

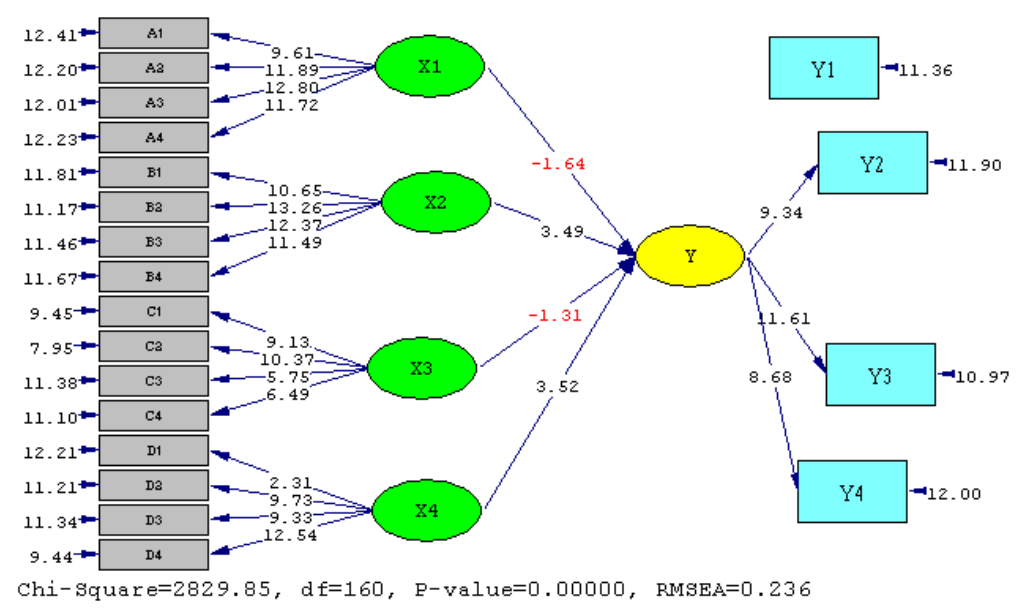

Gambar 3. Idikator Nilai Indicator

Catatan : Gambar berasal dari proses output program Lisrel (penulis, 2019)

Berdasarkan gambar 2 dan gambar 3 disimpulkan bahwa tidak ada nilai varians nilai negatif, dan nilai indikator Kepemimpinan Transactional (X1), Kepemimpinan Transformational (X2), Kepemimpinan Authentic (X3), Kepemimpinan Authoritarian (X4), dan Kinerja Guru (Y) ) di atas loading factor 0,5 $(>0,5)$ Kemudian hasil output lisrell dari masing-masing indikator dan loading factor dirangkum dalam tabel untuk analisis validitas dan reliabilitas. Ringkasan hasil analisis dapat dilihat pada tabel berikut: 
EVALUASI, 4 (1), Maret 2020, ISSN 2580-3387 (print) |

ISSN 2615-2886 (online)

Homepage : http://e-journal.staima-alhikam.ac.id/index.php/evaluasi

DOI : : http://doi.org/10.32478/evaluasi.v4i1.342

Article type : Original Research Article

Tabel 2a. Hasil Indikator Analisis Order 2 CFA

\begin{tabular}{|c|c|c|c|c|}
\hline Variabel & Indikator & $\begin{array}{l}\text { Loading } \\
\text { Factor }\end{array}$ & T-Value & Keterangan \\
\hline \multirow{4}{*}{$\begin{array}{l}\text { Kepemimpinan } \\
\text { Transactional } \\
\text { X1) }\end{array}$} & $\mathrm{A} 1$ & 0.51 & 9.61 & Valid \& Sig \\
\hline & $\mathrm{A} 2$ & 0.52 & 11.89 & Valid \& Sig \\
\hline & A3 & 0.66 & 12.80 & Valid \& Sig \\
\hline & $\mathrm{A} 4$ & 0.61 & 11.72 & Valid \& Sig \\
\hline \multirow{4}{*}{$\begin{array}{l}\text { Kepemimpinan } \\
\text { Transformational } \\
\text { (X2) }\end{array}$} & B 1 & 0.58 & 10.65 & Valid \& Sig \\
\hline & B 2 & 0.69 & 13.26 & Valid \& Sig \\
\hline & B 3 & 0.65 & 12.37 & Valid \& Sig \\
\hline & B 4 & 0.60 & 11.49 & Valid \& Sig \\
\hline \multirow{4}{*}{$\begin{array}{l}\text { Kepemimpinan } \\
\text { Authentic } \\
\text { ( X3) }\end{array}$} & C 1 & 0.59 & 9.13 & Valid \& Sig \\
\hline & $C 2$ & 0.67 & 10.37 & Valid \& Sig \\
\hline & C 3 & 0.38 & 5.75 & Valid \& Sig \\
\hline & C 4 & 0.44 & 6.49 & Valid \& Sig \\
\hline \multirow{4}{*}{$\begin{array}{l}\text { Kepemimpinan } \\
\text { Authoritarian }(x 4)\end{array}$} & D 1 & 0.55 & 2.31 & Valid \& Sig \\
\hline & D 2 & 0.56 & 9.73 & Valid \& Sig \\
\hline & D 3 & 0.54 & 9.32 & Valid \& Sig \\
\hline & D4 & 0.70 & 12.54 & Valid \& Sig \\
\hline
\end{tabular}

Catatan : Tabel berasal dari proses output program Lisrel (penulis, 2019)

Berdasarkan hasil dari pengujian data di atas menunjukkan bahwa nilai dari loading factor diperoleh semuanya di atas $0,5(>0,5)$, dan seluruh nilai t yang diperoleh terlihat lebih signifikan lebih dari 1,96 (>1,96). Ringkasan dari hasil analisis penelitian di atas dapat dilihat pada Tabel 3. 
EVALUASI, 4 (1), Maret 2020, ISSN 2580-3387 (print) |

ISSN 2615-2886 (online)

Homepage : http://e-journal.staima-alhikam.ac.id/index.php/evaluasi

DOI : : http://doi.org/10.32478/evaluasi.v4i1.342

Article type : Original Research Article

Tabel 3 Ringkasan Nilai Loading Factor

\begin{tabular}{|l|l|l|l|}
\hline Variabel & Loading Factor & T-Value & Keterangan \\
\hline Kepemimpinan Transactional & -0.33 & -1.64 & Tidak signifikan \\
Kepemimpinan Transformational & 0.80 & 3.49 & Signifikan \\
Kepemimpinan Authentic & -0.17 & -1.31 & Tidak Signifikan \\
Kepemimpinan Authoritarian & 0.73 & 3.52 & Signifikan \\
\hline
\end{tabular}

Catatan : Tabel berasal dari proses output program Lisrell (penulis, 2019)

Hasil ini dapat disimpulkan bahwa kepemimpinan transactional tidak berpengaruh signifikan terhadap kinerja perkuliahan, kepemimpinan transformational berpengaruh signifikan terhadap kinerja perkuliahan, kepemimpinan authentic tidak berpengaruh signifikan terhadap kinerja perkuliahan, kepemimpinan authoritarian berpengaruh signifikan terhadap kinerja perkuliahan.

\section{Analisis Goodness Of Fit (GOF)}

Uji kesesuaian model pada keseluruhan model fit tentang analisis statistik nilai GOF yang dihasilkan oleh program Lisrell, untuk relevansi model (model fit) yang cukup baik dan untuk modelnya sesuai dengan kriteria seperti yang ditunjukkan pada Tabel 4.

Tabel 4 Goodness Of Fit

\begin{tabular}{|l|l|l|l|}
\hline Indeks Fit & Nilai & Standar Nilai & Keterangan \\
\hline Chi-Square & 80.20 & $>0.5$ & Baik \\
\hline $\begin{array}{l}\text { Root Mean Square Error of } \\
\text { Approximation (RMSEA) }\end{array}$ & 0.04 & $<0.08$ & Baik \\
\hline Normed Fit Index (NFI) & 0.93 & $>0.90$ & Baik \\
\hline Non-Normed Fit Index (NNFI) & 0.95 & $>0.90$ & Baik \\
\hline Comparative Fit Index (CFI) & 0.95 & $>0.90$ & Baik \\
\hline
\end{tabular}


EVALUASI, 4 (1), Maret 2020, ISSN 2580-3387 (print) |

ISSN 2615-2886 (online)

Homepage : http://e-journal.staima-alhikam.ac.id/index.php/evaluasi

DOI : : http://doi.org/10.32478/evaluasi.v4i1.342

Article type : Original Research Article

\begin{tabular}{|l|l|l|l|}
\hline Incremental Fit Index (IFI) & 0.96 & $>0.90$ & Baik \\
\hline Relative Fit Index (RFI) & 0.94 & $>0.90$ & Baik \\
\hline Goodness of Fit Index (GFI) & 0.91 & $>0.90$ & Baik \\
\hline
\end{tabular}

Catatan : Tabel berasal dari proses output program Lisrell (penulis, 2019)

Berdasarkan dari hasil analisis data di atas dapat diketahui bahwa seluruh indeks fit menyatakan bahwa model baik atau fit. Hasil ini telah menunjukkan bahwa pada variabel tersebut dinyatakan valid dan akan dapat diandalkan sehingga dapat diambil kesimpulan bahwa keseluruhan model masih baik atau fit. Model persamaan (Structural Equations) linier dari 8.70 software LISREL diperoleh sebagai berikut:

\section{$Y=-0.33^{*} X 1+0.80^{*} X 2-0.17^{*} X 3+0.73^{*} X 4$, Errorvar. $=-0.055, R^{2}=0.76$ $\begin{array}{lllll}(0.20) & (0.23) & (0.13) & (0.21) & (0.079)\end{array}$ \\ $\begin{array}{lllll}-1.64 & 3.49 & -1.31 & 3.52 & -0.69\end{array}$}

Gambar 4 Persamaan Struktural

Berdasarkan hasil dari semua analisis di atas, dapat diringkas dan diperoleh persamaan regresi berikut (Kinerja Kuliah) $=-0,33 * X 1+0,80 * X 2$ $-0,17 * x 3+0,73 * x 4$.

\section{DISKUSI DAN KESIMPULAN}

Berdasarkan analisis hasil penelitian dapat disimpulkan bahwa tidak terdapat pengaruh yang signifikan Kepemimpinan Transactional (X1) terhadap Kinerja Guru (Y), Tidak ada pengaruh yang signifikan Kepemimpinan Transformational (X3) terhadap Kinerja Guru (Y). Tidak ada pengaruh signifikan Kepemimpinan Authentic (X3) terhadap Kinerja Kuliah (Y5). 
EVALUASI, 4 (1), Maret 2020, ISSN 2580-3387 (print) |

ISSN 2615-2886 (online)

Homepage : http://e-journal.staima-alhikam.ac.id/index.php/evaluasi

DOI : : http://doi.org/10.32478/evaluasi.v4i1.342

Article type : Original Research Article

Terdapat pengaruh yang signifikan antara Kepemimpinan Authoritarian (X4) dengan Kinerja Kuliah (Y). Purwanto et al. (2019) melakukan penelitian dan menyimpulkan bahwa kepemimpinan transformational dan kepemimpinan transactional memiliki pengaruh positif dan signifikan terhadap kinerja bisnis $^{10}$. Asbari et al (2019) menyatakan bahwa efek transformational juga memiliki pengaruh yang signifikan terhadap kinerja kerja ${ }^{11}$. Mirayani et al (2019) kepemimpinan authentic dan authoritarian memiliki pengaruh signifikan terhadap kinerja kerja ${ }^{12}$.

Alonderiene et al. (2016) melakukan penelitian empiris mengungkapkan dampak positif yang signifikan dari gaya kepemimpinan pada kepuasan kerja fakultas di mana gaya kepemimpinan pelayan telah ditemukan memiliki dampak signifikan positif tertinggi pada kepuasan kerja fakultas sementara mengendalikan gaya kepemimpinan autocrat memiliki dampak terendah ${ }^{13}$. Martin et al (2005) menyatakan bahwa pengaruh kepemimpinan di enam bidang utama muncul sebagai signifikan dalam penelitian: manajer lingkungan, manajer jaringan, manajer kebijakan, manajer krisis, manajer kesenjangan pengetahuan, dan persiapan pemimpin masa depan. Para penulis menegaskan bahwa pemimpin memiliki kontrol yang luar biasa terhadap lingkungan pemrosesan pengetahuan dan peran kepemimpinan memiliki pengaruh yang lebih luas daripada resolusi

${ }^{10}$ Purwanto, A., Asbari, M., \& Santoso, P.(2019).Influence of Transformational and Transactional Leadership Style toward Food Safety Management System ISO 22000:2018 Performance of Food Industry in Tangerang Central Java. Jurnal Inovasi Bisnis, 6(2), 180-185. DOI:

https://doi.org/10.35314/inovbiz.v7i2.1213

${ }^{11}$ Asbari, M., Santoso, P., \& Purwanto, A. (2019). Pengaruh Kepemimpinan dan Budaya Organisasi Terhadap Perilaku Kerja Inovatif Pada Industri 4.0. JIM UPB (Jurnal Ilmiah Manajemen Universitas Putera Batam), 8(1), 7-15. doi: https://doi.org/10.33884/jimupb.v8i1.1562

${ }^{12}$ Mirayani, R., S.Williana Kusumaningsih, \& Anggaripeni Mustikasiwi. (2019). TRANSFORMATIONAL, AUTHENTIC, AND AUTHORITARIAN TYPES OF LEADERSHIP: WHICH ONE IS THE MOST INFLUENTIAL IN STAFFS' PERFORMANCE (A Study On Performance In A Religious School Setting). Dinasti International Journal of Education Management And Social Science, 1(2), 172-182. https://doi.org/10.31933/dijemss.v1i2.68

${ }^{13}$ Alonderiene, R. and Majauskaite, M. (2016), "Leadership style and job satisfaction in higher education institutions", International Journal of Educational Management, Vol. 30 No. 1, pp. 140-164. https://doi.org/10.1108/IJEM-08-2014-0106 
EVALUASI, 4 (1), Maret 2020, ISSN 2580-3387 (print) |

ISSN 2615-2886 (online)

Homepage : http://e-journal.staima-alhikam.ac.id/index.php/evaluasi

DOI : : http://doi.org/10.32478/evaluasi.v4i1.342

Article type : Original Research Article

kesenjangan pengetahuan ${ }^{14}$. Garger et al. (2008) menemukan bahwa studi tentang kepemimpinan authentic relatif baru; definisi kerja, metode pengukuran, dan studi berbasis kriteria belum ada. Dengan demikian, upaya untuk mengembangkan pemimpin authentic hanya dapat menghasilkan pemimpin yang dilatih untuk menunjukkan perilaku kepemimpinan authentic secara dangkal ${ }^{15}$.

Penelitian Liu et al (2018) memberikan bukti empiris bahwa kepemimpinan authentic berhubungan positif dengan perilaku proaktif bawahan dan berhubungan negatif dengan perilaku penyimpangan tempat kerja bawahan melalui efek mediasi dari tiga faktor psikologis, termasuk identifikasi supervisor, keselamatan psikologis, dan keterlibatan kerja ${ }^{16}$. William et al (2019) menemukan hasil dari latihan penelitian ini menunjukkan bahwa kepala sekolah perguruan tinggi menunjukkan perilaku transactional jauh lebih sering daripada tindakan transformational yang terkait dengan distribusi model kepemimpinan authentic. Hasil ini dapat dijelaskan dalam hal tekanan yang bekerja pada pendidikan yang semakin kompetitif dan tidak merata. Singkatnya, Kepala Sekolah bertindak pragmatis dan instrumental untuk mencapai tujuan jangka pendek mereka ${ }^{17}$. Penelitian Flumerfelt et al. (2019) mengidentifikasi enam peringkat tinggi, dan tujuh paradigma kepemimpinan yang sangat terkait. Paradigma yang memiliki peringkat paling tinggi dan paling terkait adalah menghadapi ambiguitas. Hasil penelitian ini

\footnotetext{
${ }^{14}$ Martin, J. and Marion, R. (2005), "Higher education leadership roles in knowledge processing", The Learning Organization, Vol. 12 No. 2, pp. 140-151. https://doi.org/10.1108/09696470510583520

Garger, J. (2008), "Developing authentic leadership in organizations: some insights and observations", Development and Learning in Organizations, Vol. 22 No. 1, pp. 14-16. https://doi.org/10.1108/14777280810840058
}

${ }^{16}$ Liu, Y., Fuller, B., Hester, K., Bennett, R. and Dickerson, M. (2018), "Linking authentic leadership to subordinate behaviors", Leadership \& Organization Development Journal, Vol. 39 No. 2, pp. 218-233. https://doi.org/10.1108/LODJ-12-2016-0327

${ }^{17}$ Williams, Gavin, "Structural Equation Modeling Methodes In Strategy Research: Application and Issue" Research Methodology in Strategy and Management (Research Methodology in Strategy and Management, Vol. 1), Emerald Group Publishing Limited, Bingley, 2004; pp. 303-346. https://doi.org/10.1016/S1479-8387(04)01111-7 
EVALUASI, 4 (1), Maret 2020, ISSN 2580-3387 (print) |

ISSN 2615-2886 (online)

Homepage : http://e-journal.staima-alhikam.ac.id/index.php/evaluasi

DOI : : http://doi.org/10.32478/evaluasi.v4i1.342

Article type : Original Research Article

menyoroti bahwa meningkatkan paradigma kepemimpinan di sekolah madrasah aliyah adalah penting ${ }^{18}$.

\section{REFERENSI}

Alavi,Seyyed Babak and Gill, Carol, (2016). Leading Change Authentically: How Authentic Leaders Influence Follower Responses to Complex Change. ournal of Leadership \& Organizational Studies, Issue DOI: 10.1177/1548051816664681, pp. 1- 15.

Alonderiene, R. and Majauskaite, M. (2016), "Leadership style and job satisfaction in higher education institutions", International Journal of Educational Management, Vol. 30 No. 1, pp. 140-164. https://doi.org/10.1108/IJEM-08-2014-0106

Al-Musadieq, Muhammad, Nurjannah, Raharjo, Kusdi,Solimun and Fernandes, Adji Achmad Rinaldo, (2018). "The mediating effect of work motivation on the influence of job design and organizational. Journal of Management Development, 10( Emerald Publishing Limited).

Anon., n.d. Beverly Alimo-Metcalfe and Robert J. Alban-Metcalfe, 2001. The development of a new Transformational Leadership Questionnaire. Journal of Occutangerangonal and Organizational Psychology, 74(The British Psychological Society), pp. 1-27.

Asbari, M., Santoso, P., \& Purwanto, A. (2019). Pengaruh Kepemimpinan dan Budaya Organisasi Terhadap Perilaku Kerja Inovatif Pada Industri 4.0. JIM UPB (Jurnal IImiah Manajemen Universitas Putera Batam), 8(1), 715. doi: https://doi.org/10.33884/jimupb.v8i1.1562

${ }^{18}$ Flumerfelt, S. and Banachowski, M. (2011), "Understanding leadership paradigms for improvement in higher education", Quality Assurance in Education, Vol. 19 No. 3, pp. 224-247. https://doi.org/10.1108/09684881111158045 
EVALUASI, 4 (1), Maret 2020, ISSN 2580-3387 (print) |

ISSN 2615-2886 (online)

Homepage : http://e-journal.staima-alhikam.ac.id/index.php/evaluasi

DOI : : http://doi.org/10.32478/evaluasi.v4i1.342

Article type : Original Research Article

Asbari, M., Nurhayati, W., \& Purwanto, A. (2019). Pengaruh Parenting style dan Personality Genetic Terhadap Pengembangan Karakter Anak di Paud Islamic School. JURNAL AUDI: Jurnal IImiah Kajian IImu Anak dan Media Informasi PAUD, 4(2), 148-

163.http://ejurnal.unisri.ac.id/index.php/jpaud/article/view/3344

Asbari, M., Santoso, P., \& Purwanto, A. (2019). Pengaruh Iklim Organisasi dan Kepemimpinan Transformasional Terhadap Produktivitas Kerja Inovatif Pada Industri Manufaktur di Tangerang Jawa Tengah. Jurnal Produktivitas Universitas Muhammadiyah Pontianak, 7(1 2020), 62-69. doi: DOI : 10.29406/jpr.v7i1.1797

Asbari. M.,Nurhayati. W.,Purwanto.A,. (2020).The effect of parenting style and genetic personality on children character development. Jurnal Penelitian dan Evaluasi Pendidikan : 23(2).

DOI: https://dx.doi.org/10.21831/pep.v23i2.28151

Bosch, D., (2013). The Impact of Transformational Leadership on LeaderFollower Work Value Congruence. International Journal of Business and Social Research (IJBSR),, Volume vol. 3 no 8, pp. 18-31.

Chukwusa, J., (2019). Autocratic Leadership Style: Obstacle to Success in Academic Libraries. Library Philosophy and Practice e-Journal, Issue DigitalCommons@University of Nebraska - Lincoln. Chu, L.-C., 2013. The moderating role of authoritarian leadership on the relationship between the internalization of emotional regulation and the well-being of employees. Leadership, Issue DOI: 10.1177/1742715013498403, p. 1-18. Corbin, B., (2000). Entrepreneurial Leadership: Fundamentals. Carmel: Corbin Group Publishing. Erkutlu, H., 2008. The impact of transformational leadership on organizational and leadership effectiveness. Journal of Management Development, Vol. 27 (No. 7), pp. 708-726.

C. E.María, L.S. Vijande, "Reasons and constraints to implementing an ISO 22000 food safety management system: Evidence from Spain". Food Control Journal, 2014;40: 50-57, https://doi.org/10.1016/j.foodcont.2013.11.032

E.S.Ong, H. Ariwibowo, Isnawati, "Pengaruh Kepemimpinan Transformasional, Kepemimpinan Transaksional Dan Kebijakan Perusahaan Tentang Upah Pekerja Terhadap Produktivitas Kerja (Studi Pada PT "X" Di Surabaya)". Jurnal Jeksekutif, 2018;5: 334-335, https://jurnal.ibmt.ac.id/index.php/jeksekutif/article/view/200/168 
EVALUASI, 4 (1), Maret 2020, ISSN 2580-3387 (print) |

ISSN 2615-2886 (online)

Homepage : http://e-journal.staima-alhikam.ac.id/index.php/evaluasi

DOI : : http://doi.org/10.32478/evaluasi.v4i1.342

Article type : Original Research Article

Fachreza, Said Musnadi, M. Shabri Abd Majid, (2018). Pegaruh Motivasi kerja,Lingkungan Kerja,Dan Budaya Organisasi Terhadap Kinerja Karyawan Dan Dampaknya Pada Kinerja Bank. jurnal Magister Manajemen ISSN 2302-0199.

Fadhil, Achmar dan Mayowan, Yuniadi, (2018). Pengaruh Motovasi Kerja dan Kepuasan Kerja Terhadap Kinerja Karyawan AJB Bumiputra. Jurnal (JAB), vol 54 (no 1).

L. Macheka, F. A. Manditsera, R.T. Ngadze, J. Mubaiwa, L. K. Nyanga, "Barriers, benefits and motivation factors for the implementation of food safety management system in the food sector in Harare Province, Zimbabwe". Food Control Journal, 2013;34: 126-131, https://doi.org/10.1016/j.foodcont.2013.04.019

N.S. Aqmarina, H.N. Utami, A. Prasetya," Pengaruh Kepemimpinan Transformasional Dan Kepemimpinan Transaksional Terhadap Kepuasan Kerja Dan Kinerja Karyawan ( Studi Kasus Pada Karyawan Hotel Gajah Mada Malang)". Jurnal Administrasi Bisnis,2016;35:164-173, http://administrasibisnis.studentjournal.ub.ac.id/index.php/jab/article/v iew/1382

Firdaus, R.A.,Purnamasari, D., Akuba, S.F.(2019) The influence of motivation, leadership and perceived workload as intervening on teacher commitment. Journal of Education and Science Technology, 5(3) . DOI : https://doi.org/10.26858/est.v5i3.10847

F.I.Dwiantoro, "Pengaruh Gaya Kepemimpinan Tranformasional dan Tansaksional Tehadap Kinerja Organisasi Melalui Praktik TQM Pada PT. Pelayaran". Jurnal IImu Manajemen, 2017; 05:1-14, https://jurnalmahasiswa.unesa.ac.id/index.php/jim/article/download/1 $9175 / 17509+\& c d=4 \& h l=j v \& c t=c \mid n k \& g l=i d$

Flumerfelt, S. and Banachowski, M. (2011), "Understanding leadership paradigms for improvement in higher education", Quality Assurance in Education, Vol. 19 No. 3, pp. 224-247. https://doi.org/10.1108/09684881111158045

F.Rahim, V. P.K. Lengkong, L. O.H. Dotulong, "Pengaruh Kepemimpinan Transformational Dan Kepemimpinan Transaksional Terhadap Kinerja Karyawan Pada PT. PLN Wilayah Sulutenggo". Jurnal EMBA, 2018;4: 
EVALUASI, 4 (1), Maret 2020, ISSN 2580-3387 (print) |

ISSN 2615-2886 (online)

Homepage : http://e-journal.staima-alhikam.ac.id/index.php/evaluasi

DOI : : http://doi.org/10.32478/evaluasi.v4i1.342

Article type : Original Research Article

3503

https://ejournal.unsrat.ac.id/index.php/emba/article/viewFile/21623/21 326

Garger, J. (2008), "Developing authentic leadership in organizations: some insights and observations", Development and Learning in Organizations, Vol. 22 No. 1, pp. 14-16. https://doi.org/10.1108/14777280810840058

Kotzé, Martina and Nel, Petrus, (2017). Personal factor effects on authentic leadership. Journal of Psychology in Africa, Vol. 27, No. 1(Africa Scholarship Development Enterprize), p. 47-53.

Lee, C. S., (2018). Authentic Leadership and Organizational Effectiveness: The Roles of Hope, Grit, and Growth Mindset. International Journal of Pure and Applied Mathematic, Volume 118 no 19(Special), pp. 383-401.

Liu, Y., Fuller, B., Hester, K., Bennett, R. and Dickerson, M. (2018), "Linking authentic leadership to subordinate behaviors", Leadership \& Organization Development Journal, Vol. 39 No. 2, pp. 218-233. https://doi.org/10.1108/LODJ-12-2016-0327

Mboya,Millicent Atieno, Were,Susan and Otieno,Romanus Odhiambo , Month: October 2017 - March 2018. EFFECT OF AUTOCRATIC LEADERSHIP STYLE ON QUALITY ASSURANCE IN INSTITUTIONS OF HIGHER LEARNING IN KENYA. International Journal of Management and Commerce Innovations, Volume Vol. 5, Issue 2, pp. 1214-1225.

MUHUMUZA, M. V., 2015. THE INFLUENCE OF AUTHORITARIAN LEADERSHIP ON SOCIAL, POLITICAL AND ECONOMIC DEVELOPMENT: A COMPARATIVE STUDY OF ZAMBIA AND SINGAPORE, S.I.: TECHNICAL UNIVERSITY OF KENYA.

Mirayani, R., S.Williana Kusumaningsih, \& Anggaripeni Mustikasiwi. (2019).

TRANSFORMATIONAL, AUTHENTIC, AND AUTHORITARIAN TYPES OF LEADERSHIP: WHICH ONE IS THE MOST INFLUENTIAL IN STAFFS' PERFORMANCE (A Study On Performance In A Religious School Setting).

Dinasti International Journal of Education Management And Social Science, 1(2), 172-182. https://doi.org/10.31933/dijemss.v1i2.68

Martin, J. and Marion, R. (2005), "Higher education leadership roles in knowledge processing", The Learning Organization, Vol. 12 No. 2, pp. 140-151. https://doi.org/10.1108/09696470510583520 
EVALUASI, 4 (1), Maret 2020, ISSN 2580-3387 (print) |

ISSN 2615-2886 (online)

Homepage : http://e-journal.staima-alhikam.ac.id/index.php/evaluasi

DOI : : http://doi.org/10.32478/evaluasi.v4i1.342

Article type : Original Research Article

M.Birasnav, "Knowledge management and organizational performance in the service industry: The role of transformational leadership beyond the effects of transactional leadership", Journal of Business Research, 2014;67:1622-1629, https://doi.org/10.1016/j.jbusres.2013.09.006

Purwanto, A., Asbari, M., \& Santoso, P.(2019). Does Culture, Motivation, Competence, Leadership,Commitment Influence Quality Performance?. Jurnal Inovasi Bisnis, 6(2), 201-205. DOI:

https://doi.org/10.35314/inovbiz.v7i2.1210

Purwanto, A., Asbari, M., \& Santoso, P.(2019).Influence of Transformational and Transactional Leadership Style toward Food Safety Management System ISO 22000:2018 Performance of Food Industry in Tangerang Central Java. Jurnal Inovasi Bisnis, 6(2), 180-185. DOI:

https://doi.org/10.35314/inovbiz.v7i2.1213

Purwanto, A., Asbari, M., \& Santoso, P.(2019).Pengaruh Kompetensi, Motivasi, Kepemimpinan, Komitmen dan Budaya Kerja Sistem Manajemen Integrasi ISO 9001, ISO 14000 dan ISO 45001 Pada Industri Otomotif. Jurnal Produktivitas Universitas Muhammadiyah Pontianak, 6(2),158-166. DOI: http://dx.doi.org/10.29406/jpr.v6i2.1798

Purwanto, A., Asbari, M., \& Santoso, P.(2019). Does Culture, Motivation, Competence, Leadership,Commitment Influence Quality Performance?. Jurnal Inovasi Bisnis, 6(2), 201-205. DOI:

https://doi.org/10.35314/inovbiz.v7i2.1210

Purwanto, A., Asbari, M., \& Santoso, P.(2019).Influence of Transformational and Transactional Leadership Style toward Food Safety Management System ISO 22000:2018 Performance of Food Industry in Tangerang Central Java. Jurnal Inovasi Bisnis, 6(2), 180-185. DOI: https://doi.org/10.35314/inovbiz.v7i2.1213

Siti Salbiyah, Fitri Nuraini, Asyidatur Rosmaniar ( 2019 ). Motivation And Its Effect On Women's Lecturer Performance In University of Muhammadiyah Surabaya, SSRG International Journal of Economics and Management Studies (SSRG-IJEMS), 6(9), 48-55

I. F.Segovia, B. Peidro, A.Fuentes, "Implementation of a food safety management system according to ISO 22000 in the food supplement industry: A case study", Food Control Journal,2014; 43: 28-34, https://doi.org/10.1016/j.foodcont.2014.02.042

R. Wahyuniardi, H.R. Nababan, “Pengaruh Kepemimpinan Transformasional Dan Budaya Organisasi Terhadap Kepuasan Kerja Serta Dampaknya Pada 
EVALUASI, 4 (1), Maret 2020, ISSN 2580-3387 (print) |

ISSN 2615-2886 (online)

Homepage : http://e-journal.staima-alhikam.ac.id/index.php/evaluasi

DOI : $\quad:$ http://doi.org/10.32478/evaluasi.v4i1.342

Article type : Original Research Article

Kinerja Karyawan", Jurnal Teknik Industri, 2018;19:118-226, https://doi.org/10.22219/JTIUMM.Vol19.No2.118-126

Williams, Gavin, "Structural Equation Modeling Methodes In Strategy Research: Application and Issue" Research Methodology in Strategy and Management (Research Methodology in Strategy and Management, Vol. 1), Emerald Group Publishing Limited, Bingley, 2004; pp. 303-346. https://doi.org/10.1016/S1479-8387(04)01111-7

William Stoten, D. (2014), "Authentic leadership in English education: what do college teachers tell us?", International Journal of Educational Management, Vol. 28 No. 5, pp. 510-522. https://doi.org/10.1108/IJEM04-2013-0049 